\title{
Analysis of Under Passing Skills In Learning Volyballs In Man 1 Model, Bengkulu City
}

\section{Analisis Tingkat Keterampilan Passing Bawah Dalam Pembelajaran Bola Voli Di Man 1 Model Kota Bengkulu}

\author{
Doni Kurniawan"1), Feby Elra Perdima2), \\ Supriyanto ${ }^{3)}$ \\ 1,2,3 Departemen Phsycal Education Study Program, Universitas Dehasen \\ Bengkulu, Bengkulu, Indonesia
}

Corresponding Author:

feby.elra@unived.ac.id

\section{How to Cite : \\ Kurniawan, Doni, Perdima, Feby Elra \& Supriyanto. (2021). Analysis Of Under Passing Skills In Learning Volyballs In Man 1 Model, Bengkulu City. Hanoman Journal, 2 (1). DOI: https://doi.org/10.37638/hanoman.1.2.78-84}

\begin{abstract}
ARTICLE HISTORY
Received [03 September 2021] Revised [15 November 2021] Accepted [20 Desember 2021]
\end{abstract}

Kata Kunci :

Keterampilan passing bawah, pembelajaran bolavoli

Keywords :

Forearm skills, volleyball learning

\begin{abstract}
ABSTRAK
Penelitian ini bertujuan untuk: (1) Mengetahui tingkat keterampilan passing bawah dalam pembelajaran bola voli di MAN 1 MODEL Kota Bengkulu. Metode yang digunakan dalam penelitian ini adalah dengan menggunakan metode analisis deskriptif kuantitatif, dengan perhitungan populasi penelitian dijadikan sampel penelitian berdasarkan perhitungan yang berupa angka dengan perhitungan statistik. Populasi penelitian ini adalah 30 siswa. Teknik pengumpulan data dalam penelitian ini adalah teknik pengolahan data yang terlihat pada analisis data keterampilan passing bawah. Implementasi dalam penelitian ini yang digunakan adalah memberikan penilaian berupa waktu yang digunakan selama tes keterampilan passing bawah bola voli dan mengamati pelaksanaan tes yang diberikan, setelah itu diubah menjadi data T-score untuk melihat kategori keterampilan mengoper bola voli di MAN 1 MODEL Kota Bengkulu. Dari hasil analisis penelitian yang dilakukan yaitu: 13 orang $(43,33 \%)$ berada pada skor $\geq 47,12$ orang $(40,00 \%)$ berada pada skor $40-46,5$ orang $(16,67 \%)$ berada pada a. skor 27-39, 0 orang (0\%) 17-26 dan 0 orang (\%) dengan skor $<16$. Berdasarkan data hasil analisis menunjukkan bahwa tingkat keterampilan passing bawah dasar MAN 1 MODEL Kota Bengkulu termasuk dalam kategori baik dengan skor rata-rata passing bawah 44,9 .
\end{abstract}

\begin{abstract}
This study aims to: (1) Determine the level of forearm pass skills in volleyball learning in MAN 1 MODEL Bengkulu City. The method used in this research is to use quantitative descriptive analysis method, with the calculation of the study population used as research samples based on calculations in the
\end{abstract}

78 | Kurniawan, Doni, Perdima, Feby Elra \& Supriyanto. (2021). Analysis Of Under Passing Skills In... 
form of numbers with statistical calculations. The population of this research is 30 students. The data collection technique in this study is a data processing technique that looks at the data analysis of forearm pass skills. The implementation in this study used was to provide an assessment in the form of time used during the test of forearm pass skills in volleyball and observing the implementation of the tests given, after which it was converted to T-score data to see the categories of volleyball forearm pass skills in MAN 1 MODEL Bengkulu City. From the results of the research analysis carried out, namely: 13 people (43.33\%) were at a score of $\geq 47$, 12 people (40.00\%) were at a score of 40-46, 5 people (16.67\%) were at a score of 27-39, 0 people (0\%) were in 17-26 and 0 people (\%) were at a score $<16$. Based on the data, the results of the analysis show that the level of basic forearm pass skills in MAN 1 MODEL Bengkulu City is in the good category with an average score of 44.9 forearm pass.

\section{PENDAHULUAN}

Pendidikan merupakan proses pembinaan karakter yang dapat menentukan kelangsungan hidup manusia, dalam hal inilah yang menjadikan pendidikan suatu bagian terpenting dalam pembangunan suatu bangsa. Pendidikan pada umumnya merupakan suatu proses pembelajaran, pengetahuan, keterampilan, dan kebiasaan dari sekumpulan manusia yang dilanjutkan dari suatu generasi ke generasi melalui pengajaran, pelatihan, dan penelitian. Adapun hubungan pendidikan dan pendidikan jasmani adalah terletak dari aktivitas yang diarahkan untuk mencapai tujuan pendidikan. Pendidikan jasmani adalah aktivitas fisik dan juga aktivitas pendidikan, baik itu kegiatan bermain atau berolahraga. Pendidikan jasmani mempunyai peranan penting yang bertujuan untuk mengembangkan aspek kebugaran jasmani, keterampilan gerak, dan lain-lain. Pendidikan jasmani tidak lepas dari olahraga, karena pendidikan jasmani memiliki makna yang dapat diterjemahkan menurut selera dan wawasan pengetahuan masyarakat itu sendiri.

Olahraga itu sendiri merupakan sarana setiap orang meluangkan waktu untuk melakukan aktivitas jasmani. Olahraga sudah menjadi sebuah pandangan hidup bagi sebagian orang, bahkan untuk sebagian orang olahraga menjadi sebuah kebutuhan mendasar dalam hidup. Olahraga menjadi sangat penting, karena tidak terlepas dari kebutuhan mendasar manusia itu sendiri yang pada prinsipnya selalu bergerak ke arah yang diinginkan. Olahraga itu sendiri merupakan serangkaian gerak raga yang teratur dan terencana untuk memelihara dan meningkatkan kemampuan gerak yang bertujuan untuk mempertahankan hidup serta meningkatkan kualitas hidup seseorang, selain itu juga olahraga turut berperan dalam peningkatan kemampuan bangsa dalam melaksanakan sistem pembangunan yang berkelanjutan. Tujuan seseorang berolahraga adalah untuk meningkatkan kesehatan yang menyeluruh baik jasmani maupun rohani.

Olahraga mempunyai fungsi dan manfaat sesuai dengan kebutuhan, selain olahraga sebagai sarana rekreasi olahraga juga dapat pula sebagai pembelajaran. 
Peningkatan pembelajaran perlu dilaksanakan dan dibina, karena adanya dorongan dan dukungan. Sekolah salah satunya yang sangat berperan dalam meningkatkan peminatan pembelajaran adalah guru. Pembekalan pengalaman belajar pendidikan jasmani diarahkan untuk membina pertumbuhan fisik, kebugaran, dan pengembangan mental yang lebih baik sekaligus membentuk pola hidup yang sehat.

Pembelajaran merupakan kegiatan sistematis yang dapat mendorong siswa dalam membina serta mengembangkan potensi jasmani dan rohani. Sejalan dengan perkembangan dan peningkatan fisik yang beranjak matang, maka semuanya dapat terkoordinasi dengan baik dari tingkat anak-anak bahkan ke tingkat dewasa. Usia anak pada ditingkat Sekolah Menengah Atas (SMA) merupakan masa yang ideal untuk belajar yang berkaitan dengan keterampilan, seperti halnya dengan keterampilan bermain bola voli.

Bola voli merupakan jenis olahraga bola besar yang dimainkan oleh tim yang saling berlawanan, dalam satu tim berjumlah enam orang. Bola voli merupakan salah satu cabang olahraga yang digemari oleh masyarakat pada umumnya, hal ini dikarenakan olahraga bola voli dapat dimainkan dari semua lapisan masyarakat baik kalangan atas maupun kalangan bawah.

Dari beberapa penjelasan mengenai bola voli diatas dan beberapa pengalaman yang penulis observasi di MAN 1 MODEL Kota Bengkulu, penulis mendapatkan permasalahan yang ada di sekolah tersebut khususnya dalam pembelajaran bola voli mengenai keterampilan dalam passing bawah. Siswa masih mengalami kesalahan dalam melakukan gerakan tersebut, siswa juga masih kurang memahami keterampilan passing bawah dengan baik. Hal ini berdampak dalam pembelajaran yang kurang berjalan dengan baik. Passing merupakan salah satu teknik yang selalu digunakan untuk mengawali permainan, setiap siswa dalam melakukan passing harus selalu ditingkatkan guna mengikuti pembelajaran bola voli agar berjalan dengan baik. Bola Voli dicipkatan oleh Wiliam G Morgan pada tahun 1895, dia adalah seorang pembina pendidikan jasmani dari Amerika Serikat. Mulamula bola voli diberi nama Mintonette, karena permainan hampir serupa dengan permainan badminton. Jumlah pemain tidak terbatas, sesuai dengan tujuan semula untuk mengembangkan kesegaran jasmani. Kemudian Wiliam G Morgan melanjutkan idenya untuk mengembangkan permainan tersebut agar menjadi cabang olahraga yang dipertandingkan, nama permainan kemudian dirubah menajdi VolleyBall.

Bola voli di Indonesia sudah dikenal sejak tahun 1928 dibawah oleh guruguru belanda yang mengajarkan di sekolah-sekolah lanjutan, kemudian berkembang di Indonesia pada tanggal 22 Januari 1955 di Jakarta sekaligus diresmikan dan berdirinya PBVSI (Persatuan Bola Voli Seluruh Indonesia). Seiring berjalannya waktu, bola voli merupakan olahraga yang sangat populer. Bola voli termasuk ke dalam permainan bola besar, permainan bola voli merupakan suatu permainan cabang olahraga berkembang yang sangat digemari oleh semua lapisan masyarakat baik dari anak-anak sampai orang tua, laki-laki maupun perempuan, masyarakat perdesaan sampai masyarakat kota. "Bola Voli sudah dikenal sejak abad

80 | Kurniawan, Doni, Perdima, Feby Elra \& Supriyanto. (2021). Analysis Of Under Passing Skills In... 
pertengahan, terutama negara-negara romawi" (Yoenoes, 2009:2). Bola voli adalah salah satu permainan yang sangat banyak digemari masyarakat, karena selain tergolong cabang olahraga prestasi juga lebih dominan mengarah ke unsur olahraga rekreasi yang berdampak kesenangan.

Menurut Barbara L. Viera (2004:19), passing bawah atau operan lengan bawah merupakan teknik dasar bola voli yang harus dipelajari lebih. Barbara mengatakan bahwa "Operan ini biasanya menjadi teknik pertama yang digunakan tim bila tidak memegang servis. Operan ini digunakan untuk menerima servis, menerima spike, memukul bola setinggi pinggang ke bawah dan memukul bola terpantul di net". Ada beberapa prinsip umum dalam melakukan passing bawah. Di samping unsur kondisi fisik, taktik, dan mental mengembangkan mutu prestasi permainan bola voli merupakan salah satu unsur yang menentukan menang atau kalah suatu tim di dalam pertandingan. Adapun manfaat dalam olahraga bola voli ini diantaranya menyenangkan juga dapat mempererat tali persaudaraan dalam keluarga, sanak saudara, antar tetangga dan lain sehingga tercipta suasana santai dan rukun.

Menurut Erianti (2004:23), ide dasar permainan bola voli adalah "melewatkan bola ke daerah lawan melalui di atas net dan berusaha mematikan bola di daerah lawan". Setiap orang melakukan permainan ini mempunyai tujuan yang berbeda-beda, ada yang bertujuan untuk memperluas pergaulan, kesehatan bahkan tidak sedikit yang berusaha untuk berprestasi. Dari tahun ke tahun perkembangan cabang olahraga bola voli berkembang dengan pesat. Keterampilan merupakan kemampuan ataupun keahlian seseorang dalam melakukan suatu gerakan, untuk memiliki keterampilan menguasai seluruh teknik yang baik perlu diperkenalkan dan dilatih dari usia dini yang nantinya diharapkan atlet ataupun olahragawan tersebut dapat memiliki bakat berprestasidalamolahragakhususnyaolahraga bolavoli.

Menurut Hidayat (2017:43) menjelaskan, passing merupakan teknik menerima boladan mengayunkan kembali kearah yang diinginkan. Teknik ini merupakan teknik dasar permainan bolavoli dan harus diketahui oleh mereka yang ingin melakukan permainan tersebut.Passing bawah merupakan elemen utama untuk mempertahankan regudari serangan lawan (bolayang datangnya terlalu keras dan sulit dimainkan dengan passing atas, maka diambil dengan passing bawah (Erianti, 2004:159).

\section{METODE PENELITIAN}

Metode penelitian pada penelitian ini adalah dengan menggunakan analisis deskriptif kuantitatif. Penelitian pada dasarnya adalah suatu kegiatan ilmiah untuk memperoleh pengetahuan yang benar tentang suatu masalah (Trijono, 2015.15). Adapun prosedur penelitiannya adalah dengan menganalisa dalam mengetahui tingkat keterampilan passing dalam pembelajaran bola voli di MAN 1 MODEL Kota Bengkulu, dalam beberapa upaya bentuk keterampilan passing bawah. 


\section{HASIL}

Data yang diperoleh dari tes tersebut digunakan untuk mengkategorikan menjadi limakategori yaitu, baik sekali, baik, sedang, kurang dan kurang sekali. Untuk menentukan kategori tersebut, terlebih dahulu data dikumpulkan kemudian dikategorikan sesuai dengan normates keterampilan dasar passing bawah. Data penelitian untuk skor keterampilan passing bawah, didapatkan data bahwa skor tertinggi 46 dan skor terendah 15. Dari analisis data diperoleh rata-rata (Mean) sebesar 44.9. 13 orang (43.33\%) berada pada skor $\geq 47,12$ orang (40.00\%) berada pada skor 40-46, 5 orang (16.67\%) berada pada skor 27-39, 0 orang (0\%) berada pada skor 17-26, 0 orang (0\%) berada pada skor $<16$.

Berdasarkan hasil tes, di dapatlah data bahwa terdapat lima kategori yaitu“baik sekali, baik, sedang, kurang dan kurang sekali”. Lima kategori ini di jelaskan sebagai berikut:Norma Tes Keterampilan Passing Bawah. Berdasarkan penjelasan di atas, maka dapat di jelaskan bahwa: 13 orang dalam kategori baik sekali, 12 orang dalam kategori baik, 5 orang dalam kategori sedang, 0 orang dalam kategori kurang, dan 0 orang dalam kategori kurang sekali.

\section{PEMBAHASAN}

Penelitian ini merupakan penelitian deskriptif kuantitatif, dimana pengambilan data menggunakan tes keterampilan passing bawah menggunakan Tes Keterampilan (Pusat Pengembangan Kualitas Jasmani). Tujuan dari penelitian ini adalah untuk mengetahui tingkat keterampilan Passing bawah, diperoleh hasil tes tingkat keterampilan passing bawah yaitu: 13 orang (43.33\%) berada pada skor $\geq 47$, 12 orang (40.00\%) berada pada skor 40-46, 5 orang (16.67\%) berada pada skor 2739,0 orang (0\%) berada pada skor $17-26$, dan 0 orang (0\%) berada pada skor $<16$

Berdasarkan data hasil analisis menunjukkan bahwa tingkat keterampilan dasar passing bawah pada MAN 1 MODEL Kota Bengkuludalam kategori "BAIK" dengan rata-rataSkor 44.9 passing bawah, karena siswa tersebut dilatih oleh guru yang memahami dalam program latihan. Pada saat latihan melibatkan peran aktif dari guru di dalam melihat dan mengoreksi apa yang telah dilakukan anak tersebut untuk mencari masalah yang telah diberikan, dalam bentuk latihan membandingkan dengan siswa bagaimana mereka malakukannya, mengatur, mengelompokkan serta membuat kesimpulan dan mengidentifikasi saat pencarian kecocokan dari sebuah bentuk latihan. Kesalahan dari telaah dikoreksi oleh guru dan menunjukkan bagaimana sebenarnya suatu kesempurnaan gerakan dalam latihan.

Faktor lain yang juga memiliki peran penting dalam peningkatan keterampilan dasardan juga prestasi olahraga adalah motivasi serta kedisiplinan dari dalam diri seseorang. Pada dasarnya suatu aktivitas, kegiatan atau tingkah laku yang dilakukan oleh seseorang selalu didasari oleh adanya kedisiplinan dan motivasi yang tinggi dari dalam diri seseorang. Untuk mendapatkan hasil latihan yang baik, tentu dengan metode yang benar. Oleh karena itu, kemampuan pelatih baik 
pengetahuan maupun keterampilan menjadi hal yang sangat penting yang harus dimiliki sampai kepada hal-hal terkecil dibidang cabang olahraga yang dilatihnya. Pengetahuan tersebut termasuk penguasaan teknik, taktik, peraturan pertandingan, sistem-sistem atau metode latihan, strategi latihan, psikologi anak, mempunyai motivasi dan hal mendetail lainnya di dalam olahraga khususnya pada bolavoli. Semuanya harus dipahami dan dikuasai oleh seorang guru tersebut.

\section{KESIMPULAN DAN SARAN}

Berdasarkan hasil penelitian dan pembahasan, dapat di simpulkan bahwa keterampilan passing bawah dengan 30 orang pada kategori Baikdengan skor 44.9. Bagi siswa, agar siswa lebih bersemangat dan bersungguh-sungguh dalam mengikuti latihan atau belajar penjas nantinya. Bagi guru nantinya, semakin di tingkatkan kembali bentuk-bentuk latihannya. Bagi stakeholder olahraga lebih memperhatikan kembali dalam pembinaan di Kaur. Bagi peneliti selanjutnya, dapat mengembangkan penelitian ini dengan menambah unsur-unsur lain yang lebih luas seperti keterampilan dasar Bola Voli

\section{DAFTAR PUSTAKA}

1. Aahper. 1999. Physical Education For Life Long Fitnes. The Best Teacher's Guide, IL:Human Kinetics

2. Barbara L.Viera,Ms.jill Ferguson, Bonie, Ms.2000. Tingkat Pemula Bola Voli. Jakarta:PT Raja Grapindo Persada.

3. Erianti. 2004.Buku Ajar Bola Voli. Padang:SUKABINA Press.

4. Hidayat,Witono.2017. Buku Pintar Bola Voli. Jakarta:Anugrah.

5. Maulida Kbafidoh. 2018. Peningkatan Kemampuan Teknik Dasar Permainan Bola Voli Untuk Mendukung Pengembangan Kecerdasan Kinestetik Siswa Melalui Ekstrakurikuler Bola Voli di MI Negeri 4 Banjarnegara (Skripsi Publish).

6. Nazir,Moh. 2011. Metode Penelitian. Bogor: Ghalia Indonesia.

7. Sofyan, Achmad Hanif.2011. Kepelatihan Dasar Sepak Takraw. Jakarta: PT Bumi Timur Jaya.

8. Subagyo,P.Joko.2015.Metode Penelitian Dalam Teori Dan Praktek .Jakarta: Rineka Cipta

9. Subroto, Toto.2000.Keterampilan Dan Konsep Olahraga Di Sekolah Dasar. Bandung.UPI.

10. Sukadiyanto, dan Dangsina Muluk. 2011. Pengantar Teori Dan Metodologi Melatih Fisik. Bandung : CV. Lubuk Agung.

11. Sukardi.2016. Metodologi Penelitian Pendidikan. Jakarta: PT Bumi Aksara.

12. Supriadi. 2018. Survei Kemampuan Passing Bawah Bola Voli siswa Kelas VII SMP Negeri 26 Makasar. (SkripsiPublish). 
13. Widiastuti. 2011.Tes Dan Pengukuran Olahraga. Jakarta: PT Bumi Timur Jaya. 14. Yoenoes,Yunan. 2009.Teknik Olahraga Bola Voli. Jakarta : CV.Ipa Abong. 